\title{
Analisis Kejiwaan Tokoh Nuning dalam Naskah Drama Nuning Bacok Karya Andy Sri Wahyudi (Kajian Psikologi Sastra)
}

\author{
Farida Nur Safitri ${ }^{1}$ \\ Suntoko ${ }^{2}$ \\ Wienike Dinar Pratiwi ${ }^{3}$
}

\section{1,2,3Pendidikan Bahasa dan Sastra Indonesia, Universitas Singaperbangsa Karawang}

11710631080058@student.unsika.ac.id,

2suntoko@fkip.unsika.ac.id,

${ }^{3}$ wienike.dinar@fkip.unsika.ac.id

\begin{abstract}
Abstrak
Penelitian ini memiliki tujuan untuk mengungkapkan kejiwaan tokoh Nuning dalam naskah drama Nuning Bacok karya Andy Sri Wahyudi dengan menggunakan pendekatan psikologi sastra. Kajian ini dibagi menjadi dua pokok pembahasan yaitu; 1) Struktur kepribadian, dan 2) Mekanisme pertahanan dan konflik. Dua pokok pembahasan tersebut digunakan untuk mengungkapkan kejiwaan dari tokoh Nuning. Penelitian ini menggunakan pendekatan kualitatif dengan metode penelitian yang digunakan adalah metode deskriptif kualitatif. Subjek dalam penelitian ini adalah naskah drama Nuning Bacok karya Andy Sri Wahyudi yang diterbitkan dalam buku antologi drama yang berjudul Dramaturgi Rasa 10 Lakon Lelakon 2020 pada tahun 2020. Teknik pengumpulan data dalam penelitian ini menggunakan teknik penelitian kepustakaan dengan metode pengumpulan data yang digunakan dalam penelitian ini adalah teknik Baca-Catat. Hasil penelitian dibagi menjadi dua pokok pembahasan yaitu yang petama adalah pembahasan struktur kepribadian tokoh Nuning dan ditemukan tiga struktur yaitu; 1) Id, 2) Ego, dan 3) Superego. Pokok pembahasan yang kedua adalah mekanisme pertahanan dan konflik yang terjadi dalam diri tokoh Nuning. Dalam naskah drama Nuning Bacok ditemukan lima mekanisme pertahanan dan konflik yang ada dalam diri tokoh Nuning yaitu; 1) Represi, 2) Sublimasi, 3) Rasionalisasi (Rationalization), 4) Reaksi Formasi (Reaction Formation), dan 5) Agresi dan Apatis.
\end{abstract}

Kata kunci: Naskah Drama, Psikologi Sastra, Kejiwaan, Struktur Kepribadian, Mekanisme Pertahanan dan Konflik

\section{Pendahuluan}

Sekarang ini fenomena dan permasalahan-permasalah yang berkaitan dengan kejiwaan banyak terjadi di sekitar kita. Banyak kasus-kasus dan permasalahan yang dapat berdampak dan menyebabkan gangguan pada perkembangan kejiwaan seseorang. Seperti ketika adanya konflik di keluarga antara orang tua, maka hal ini akan menyebabkan perkembangan kejiwaan anak terganggu. Sikap orang tua pada anak di masa kecil juga berdampak pada perkembangan kejiwaan seorang anak. 
Banyak cara yang dapat dilakukan untuk mencegah permasalahan kejiwaan ini seperti dari perhatian yang ada di lingkungan keluarga, lingkungan sekitar, sekolah, dan lain sebagainya. Cara-cara ini dapat dilakukan untuk mengatasi atau mencegah timbulnya permasalahan kejiwaan setiap individu. Salah satu media yang dapat digunakan dalam mengatasi dan mecegah permasalahan kejiwaan adalah karya sastra. Salah satu jenis karya sastra yang tepat untuk digunakan adalah naskah drama.

Naskah drama merupakan karya sastra yang tepat dalam menonjolkan tokoh-tokoh yang ada didalamnya. Naskah drama adalah karya sastra yang didalamnya terdapat tokoh-tokoh yang memiliki berbagai jenis kepribadian. Sumaryanto (2019:18) mengatakan naskah drama tidak hanya menonjolkan seni peran, tetapi juga sarat akan pesan. Pesan-pesan tersebut akan tergambarkan melalui tindakan-tindakan yang diperankan oleh tokoh dalam cerita.

Tokoh-tokoh dalam naskah drama dapat mempresentasikan setiap individuindividu di masyarakat dengan berbagai karakter yang ada. Dengan naskah drama ini, pengarang dapat menggambarkan kepribadian seseorang melalui dialog-dialog yang terdapat didalamnya. Dari dialog-dialog tersebut kita akan mendapatkan gambaran dari kejiwaan dan kepribadian tokoh-tokoh yang ada. Maka dari itu, naskah drama sangat berkaitan erat dengan psikologi.

Namun sekarang ini, seni teater masih kurang diminati di lingkungan masyarakat. Komunitas-komunitas seni teater masih sedikit dan kurang banyak dalam melakukan pementasan. Di sekolah-sekolah dan lembaga pendidikan lainnya juga masih jarang yang memiliki kegiatan teater didalamnya. Hal ini berdampak dalam kurangnya minat masyarakat pada seni teater karena kurangnya pertunjukkan-pertunjukkan teater atau drama.

Di masyarakat sendiri, pertunjukkan seni teater jarang dipertunjukkan. Kurangnya komunitas teater di lingkungan peneliti yaitu daerah Bekasi membuat masyarakat menjadi kurang mengenal pertunjukkan teater. Komunitas teater di Bekasi sendiri bisa dikatakan hanya hitungan jari yang masih aktif. Dengan komunitas yang semakin sedikit ini membuat pengenalan teater di masyarakat kurang meluas. Masyarakat lebih meminati hiburan di televisi dibandingkan dengan menonton pertunjukkan seni teater.

Kurangnya minat masyarakat pada pertunjukkan teater sangat disayangkan karena seni teater atau drama sendiri memiliki keunggulan dalam penyampaian pesan dan amanat yang lebih mudah untuk ditangkap oleh masyarakat dibandingkan dengan jenis sastra atau bentuk seni lainnya. Alasan peneliti memilih naskah drama Nuning Bacok karya Andy Sri Wahyudi sebagai objek penelitian adalah karena cerita dalam naskah drama ini dapat menggambarkan persoalan dan masalah-masalah kejiwaan yang sering dialami dan terjadi di masyarakat kita.

Naskah drama Nuning Bacok adalah naskah drama karya Andy Sri Wahyudi. Naskah drama ini ditulis berdasarkan pengalaman yang didapat dari seorang wanita pemilik Impian Studio yaitu Sulistyawati. Naskah drama Nuning Bacok adalah naskah drama monolog yang ditulis pada tahun 2016 dan sudah beberapa kali dipentaskan diberbagai tempat, seperti oleh Forum Aktor Yogyakarta di Lembaga Indonesia Prancis (sekarang: IFI) di Yogyakarta (2016), Lanjong Art Festival di Kalimantan Timur (2017), dan di Sekolah Tinggi Ilmu Ekonomi Agama Islam Yoyakarta (2017).

Pada tahun 2020 Naskah drama Nuning Bacok diterbitkan dalam Buku Antologi Drama Dramaturgi Rasa 10 Lakon Lelakon 2020. Naskah-naskah drama yang termuat dalam buku tersebut adalah naskah-naskah yang terpilih dari 178 naskah dari 19 provinsi di Indonesia. Naskah drama yang terpilih sebanyak 10 naskah drama, naskah drama tersebut adalah sebagai berikut; Perempuan dan Panci Nasi, Bis Malam, Cinta dan 
Sepotong Tahu, Nuning Bacok, Manufaktur Anatomi Kera, Rarudan, Jangkar Babu Sangkar Madu, Mata Air Mata, Lidah, dan Elliot.

Naskah drama Nuning Bacok bercerita tentang perjalanan hidup seorang wanita bernama Nuning. Naskah ini membagi kehidupan Nuning menjadi beberapa bagian yaitu latar belakang Nuning, munculnya napas dangdut dalam diri Nuning, Konflik antara Nuning dengan orang tuanya, Cinta dan pernikahan Nuning, Nuning berkeluarga, Nuning memutuskan untuk sendiri dan bahagia, lalu yang terakhir cita-cita dan lahirnya Neo Nuning.

Naskah drama ini juga menarik saat dipentaskan dan dapat membuat penonton antusias untuk melihatnya. Penonton ditunjukkan bagaimana kehidupan Nuning yang dalam kehidupan nyata sering menjadi buah bibir masyarakat yaitu seseorang yang pintar mengaji dan dengan orang tua yang taat agama namun berprofesi sebagai penyanyi dangdut walaupun tidak bertahan lama. Penonton juga diperlihatkan bagaimana kepribadian Nuning yang berbeda ketika dia menjadi seorang penyanyi dan ketika ia menjadi seorang ibu yang juga harus bekerja.

Sebuah naskah drama tidak akan lepas dari unsur-unsur yang membangunnya, begitu juga dengan naskah drama Nuning Bacok. Naskah drama ini memiliki unsur-unusr instrinsik yang terlebih dahulu dapat dianalisis, unsur-unsur tersebut meliputi tema, alur, tokoh dan penokohan, latar, dialog, amanat, dan petunjuk teknis. Unsur-unsur tersebut perlu dianalisis karena akan saling berhubungan di setiap unsurnya. Analisis ini juga yang akan menjadi dasar dalam menganalisis aspek kejiwaan tokoh.

Psikologi sastra digunakan untuk menganalisis aspek-aspek kejiwaan dan kepribadian tokoh-tokoh dalam naskah drama. Menurut Sehandi (2018:42), Psikologi sastra adalah analisis terhadap karya sastra dengan mempertimbangkan relevansi aspekaspek kejiwaan yang terkandung didalamnya. Naskah drama Nuning Bacok tepat dikaji dengan menggunakan psikologi sastra karena naskah ini sangat erat kaitannya dengan aspek psikologi. Kehidupan Nuning dari ia remaja dan pengalaman-pengalaman yang ia dapat ketika ia masih remaja yang membentuk kepribadian dan kejiwaanya ketika ia dewasa.

Teori Psikoanalisis Sigmund Freud dipilih sebagai landasan dalam menganalisis kejiwaan tokoh. Teori psikoanalisis Sigmund Freud ini digunakan karena memiliki kejelasan dalam menganalisis struktur kejiwaan manusia, selain itu teori ini juga menjelaskan tentang mekanisme pertahanan konflik manusia. Dengan teori psikoanalisis Sigmund Freud peneliti dapat menganalisis tindakan-tindakan yang dilakukan tokoh melalui dialog-dialog dan petunjuk laku dalam naskah drama.

\section{Kajian Teori}

\section{a. Hakikat Drama dan Naskah Drama}

Menurut Endraswara (2014: 13), drama adalah karya yang memiliki daya rangsang cipta, rasa, dan karsa yang amat tinggi. Dalam bahasa perancis drama disebut drame (Soemanto, dalam Endraswara 2014:11) yang artinya lakon serius. Riantiarno (2011: 4) berpendapat bahwa drama adalah hasil seni sastra (naskah) yang ungkapannya dalam wujud teater menekankan pada kekuatan unsur suara (kata, ucapan, dialog) baik yang tesurat maupun tersirat.

Berdasarkan beberapa pengertian drama menurut ahli yang telah diuraikan di atas, maka dapat disimpulkan bahwa drama adalah suatu seni pertunjukkan yang mempertunjukkan sebuah lakon hidup yang dikemas secara menarik dengan dialogdialog yang telah disusun berdasarkan naskah drama dan diperankan oleh seorang pemain atau aktor dengan didukung oleh berbagai komponen seperti sutradara, tata 
panggung, tata lampu, tata busana, dan tata rias. Kisah sebuah drama biasanya diambil oleh kisah nyata atau dari permasalahan-permasalahan yang terjadi di masyarakat

Naskah drama merupakan sebuah karangan yang berisi cerita atau lakon. Dalam naskah juga termuat nama-nama tokoh dalam cerita, karakter tokoh, dialog yang diuacapkan, dan keadaan panggung yang diperlukan. Naskah drama tidak mengisahkan cerita secara lugas dan langsung, karena lebih mementingkan ucapan-ucapan atau dapat dikatakan penuturan ceritanya diganti menggunakan dialog. Naskah drama biasanya ditulis secara lengkap dengan keterangan-keterangan seperti petunjuk laku yang meliputi gerakan-gerakan dan tindakan-tindakan yang dilakukan tokoh, dan tempat terjadinya peristiwa, perlengkapan logistik yang dibutuhkan di panggung. Sebuah naskah drama memiliki fungsi yaitu sebagai berikut (Susantono, 2016:27) 1) Sebagai acuan utama bagi sutradara, tim kreatif, tim artistik, tim teknis, aktor dan musisi, untuk membentuk pertunjukkan. 2) Sebagai medium komunikasi dan koordinasi seluruh pihak yang terlibat produksi. 3) Sebagai acuan untuk membut jadwal latihan dan produksi. 4) Sebagai acuan untuk menentukan spesifikasi dan volume kebutuhan produksi yang berkaitan dengan aspek kreatif, artistik, maupun teknis.

\section{b. Psikologi Sastra}

Psikologi sastra yaitu sebuah hasil kejiwaan sang pengarang yang dituangkan dalam bentuk sebuah karya (Melati, et al. 2019: 229). Dalam kaitannya dengan psikologi, Wellek dan Warren (Ahmadi, 2015:2) menyatakan bahwa kajian terhadap sastra dengan menggunakan psikologi dapat dilakukan dengan menggunakan psikologi dapat dilakukan melalui empat ranah, yakni (1) studi psikologi pengarang sebagai tipe atau pribadi, (2) studi proses kretif, (3) studi tipe dan hukum-hukum psikologi yang diterapkan pada karya sastra, dan (4) mempelajari dampak sastra pada pembaca atau yang disebut dengan istilah psikologi pembaca.

\section{a) Struktur Kepribadian Menurut Sigmund Freud}

Freud membagi struktur kepribadian manusia menjadi tiga yaitu, id, ego, dan superego. Id merupakan reservoir pulsi dan menjadi sumber energi psikis. Id berada dibawah alam sadar, maka dari itu id disebut sebagai naluri yang membuat manusia harus bisa memenuhi kebutuhannya seperti: makan, seks, menolak rasa sakit atau tidak nyaman (Minderop, 2011: 21).

Ego berkembang dari Id agar orang mampu menangani realita; sehingga ego beroperasi megikuti prinsip realita (reality principle); usaha memperoleh kepuasan yang dituntut Id dengan mencegah terjadinya tegangan baru atau menunda kenikmatan sampai ditemukan obyek yang nyata-nyata dapat memuaskan kebutuhan (Alwisol, 2018: 17).

Superego adalah kekuatan moral dan etik dari kepribadian, yang beroperasi memakai prinsip idealistik (idealistic principle) sebagai lawan dari prinsip kepuasan id dan prinsip realistik dari ego (Alwisol, 2018: 18). Superego berkembang dari ego, dan seperti ego dia tidak mempunyai energi sendiri.

\section{b) Mekanisme Pertahanan dan konflik}

1. Represi

Menurut Freud, mekanisme pertahanan yang paling kuat salah satunya adalah represi (repression), Freud (Minderop, 2011: 32) mengatakan bahwa konsep aktivitas mental bawah sadar, represi, resistensi dan pemindahan merupakan pilar fundamental psikoanalisis. Tugas represi ialah mendorong keluar dorongandorongan id yang tidak diterima oleh alam sadar agar kembali pada alam bawah sadar. 


\section{Sublimasi}

Menurut Piliang (2016:167) sublimasi yaitu suatu cara untuk mengalihkan energi ke saluran lain, yang secara sosial umumnya bisa diterima bahkan ada yang dilkagumi. Mekanisme ini dianggap positif karena mampu mengubah impuls yang tidak diterima menjadi bentuk yang diterima secara sosial.

3. Rasionalisasi

Rasionalisasi memiliki dua tujuan: pertama, untuk mengurangi kekecewaan ketika kita gagal mencapai suatu tujaun; dan kedua, memberikan kita motif yang dapat diterima atas perilaku (Hilgard, et al., dalam Minderop, 2011:35). Contoh-contoh rasionalisasi: Pertama, rasa suka atau tidak suka sebagai alasan. Kedua, menyalahkan orang lain atau lingkungan sebagai alasan. Ketiga, kepentingan sebagai alasan.

\section{Reaksi Formasi}

Reaksi formasi ini adalah tindakan yang dilakukan oleh manusia untuk menutupi atau menyembunyikan fakta yang sebenarnya. Biasanya hal-hal yang ditutupi adalah perilaku, perbuatan, atau fakta yang berupa kesalahan dan ditutupi oleh suatu tindakan yang lebih baik.

5. Agresi dan Apatis

Agresi dibagi menjadi dua bentuk yaitu langsung dan pengalihan (Miderop, 2011: 38). Agresi langsung yaitu agresi yang diucapkan langsung pada objek yang menjadi sumber kekecewaan. Agresi pengalihan adalah agresi yang tidak dapat diungkapkan secara langsung pada objek yang menjadi sumber kekecewaan. Apatis adalah bentuk lain dari reaksi terhadap kekecewaan, yaitu sikap apatis (apathy) dengan cara manarik diri dan bersikap seakan-akan pasrah.

\section{Metode Penelitian}

Penelitian ini menggunakan pendekatan kualitatif. Pendekatan kualitatif ini digunakan untuk menganalisis isi dari Naskah drama Nuning Bacok dan menghasilkan data deskriptif. Metode yang digunakan dalam penelitian ini adalah metode deskriptif kualitatif. Metode deskriptif kualitatif digunakan, karena dalam penulisan hasil penelitian ini data yang dihasilkan adalah berupa narasi dan kutipan-kutipan data dari naskah drama Nuning Bacok karya Andy Sri Wahyudi. Subjek dalam penelitian ini adalah naskah drama Nuning Bacok karya Andy Sri Wahyudi yang diterbitkan dalam buku antologi drama yang berjudul Dramaturgi Rasa 10 Lakon Lelakon 2020 pada tahun 2020. Teknik pengumpulan data dalam penelitian ini menggunakan teknik penelitian kepustakaan. Dalam pengumpulannya, pengumpulan data ini menggunakan metode teknik baca-catat.

Dalam pengumpulan data, terlebih dahulu peneliti menyiapkan bahan-bahan yang digunakan dan menunjang dalam pengumpulan data. Secara sistematis, adapun langkahlangkah pengumpulan data dalam analisis naskah drama Nuning Bacok yaitu: 1) Mengumpulkan bahan-bahan yang digunakan dan menunjang dalam pengumpulan data. 2) Membuat kartu data penelitian untuk mencatat data-data yang dibutuhkan, 3) Mencatat unsur-unsur instrinsik dalam naskah drama Nuning Bacok dalam kartu data, 4) Mencatat struktur kepribadian dalam naskah drama Nuning Bacok dalam kartu data, 5) Mencatat mekanisme pertahanan dan konflik dalam naskah drama Nuning Bacok dalam kartu data. 6) Menyaring data yang sudah tercatat dalam kartu data untuk di analisis.

Penelitian ini menempuh tiga tahap dalam menganalisis data. Miles dan Hubermen (Sugiyono, 2018:246), mengemukakan bahwa aktivitas dalam analisis data kualitatif dilakukan secara interaktif dan berlangsung secara terus-menerus sampai tuntas, 
sehingga datanya sudah jenuh. Aktivitas dalam analisis data, yaitu: data reduction, data display, dan conclusion drawing/verification.

\section{Hasil dan Pembahasan}

Penelitian ini menggunakan teori psikoanalisis dengan membagi pembahasan kejiwaan tokoh Nuning menjadi dua pokok pembahasan yaitu struktur kepribadian tokoh Nuning dan mekanisme pertahanan dan konflik yang ada dalam diri tokoh Nuning.

\section{a) Struktur Kepribadian Tokoh Nuning}

Tingkah laku menurut Freud, merupakan hasil konflik dan rekonsiliasi ketiga sistem kepribadian tersebut. Faktor-faktor yang memengaruhi kepribadian adalah faktor historis masa lampau dan faktor kontemporer, analoginya faktor bawaan dan faktor lingkungan dalam pembentukan kepribadian individu (Minderop, 2011:20). Freud membagi struktur kepribadian manusia menjadi tiga yaitu, id, ego, dan superego.

\section{Id}

Dalam naskah drama Nuning Bacok khususnya pada tokoh Nuning terdapat unsur Id yang terdapat dalam dialog maupun petunjuk teknis di bawah ini.

DATA 1

Kembali NUNING mengaji. Suaranya mendayu lembut. Lagi-lagi terdengar suara barang-barang perkakas berjatuhan. Cahaya menyorot ke barang pecah belah yang berantakan.

NUNING terperanjat kaget.

(Abe, 2020:89)

Pada kutipan data 1 terdapat salah satu dari mekanisme dasar Id yaitu tindakan refleks. Tindakan refleks yang terdapat dalam kutipan di atas adalah berupa rasa kaget yang dirasakan oleh tokoh Nuning. Kata 'terperanjat' dalam kutipan tersebut menggambarkan adanya gerakan pada tokoh Nuning yang berasal dari rasa kaget yang ia rasakan saat mendengar suara perkakas yang berjatuhan.

DATA 2

NUNING : - Mikirin perkembangan anak, ekonomi, dan hhmm... su-ami.

NUNING tertunduk lalu mendongakkan kepalanya tersenyum lebar.

NUNING : Mas Wawan... Mas Wawan...

(Abe, 2020:91)

Dari kutipan data 2 dapat dilihat bahwa terdapat tindakan refleks yang dilakukan oleh tokoh Nuning. Dari dialog sebelumnya dapat dilihat bahwa tindakan refleks yang dilakukan oleh Nuning disebabkan oleh dirinya yang mengingat suaminya. Bayangan tentang suaminya memicu tindakan reflek dari diri Nuning yang berupa senyuman. Hal ini ditegaskan dengan kalimat 'NUNING tertunduk lalu mendongakkan kepalanya tersenyum lebar'.

DATA 3

Lampu meredup lalu mati. Terdengar suara detak jam dinding. Terdengar suara, NUNING mimpi tentang segala keindahan dan cita-cita.

(Abe, 2020:91) 
Selain tindak refleks, dalam mekanisme dasar Id juga terdapat proses primer. Pada kutipan data 3 terdapat salah satu ciri dari proses primer yaitu membayangkan. Dalam kalimat 'NUNING mimpi tentang segala keindahan dan cita-cita' terlihat bahwa Nuning bermimpi tentang suatu keindahan yang dulu pernah terjadi, hal ini disebabkan bahwa keadaan yang sekarang tidak lagi indah seperti dahulu dan membuat Nuning membayangkan keadaan di masa lalu.

DATA 4

NUNING : - Kurasa semua perempuan sama, ia memandang dirinya sebagai seorang putri yang akan bertemu dengan pangeran pujaannya. Seorang pangeran berkuda putih yang gagah berani, yang akan melindunginya setiap saat, yang akan mencintainya sepanjang waktu. Putri dan pangeran yang akan hidup bahagia berama anak-anaknya di sebuah puri asmara. Abadi selamanya. Aiiihh... aiihh... indahnya... kuakui, aku ini memang generasi Putri Cinderalla. -

(Abe, 2020:105)

Dari kutipan dialog data 4 dapat dilihat bahwa terdapat ciri proses primer yaitu mengkhayal. Dalam kutipan tersebut Nuning membayangkan kehidupannya seperti seorang putri yang hidup bahagia dengan pangeran yang mencintainya sebuah kehidupan yang didambakan oleh tokoh Nuning. Tentunya khayalan ini hanya ada dalam pikiran Nuning dan tidak ada dalam realitanya seperti apa yang menjadi ciri dari proses primer.

\section{Ego}

Dalam naskah drama Nuning Bacok khususnya pada tokoh Nuning terdapat unsur Ego yang terdapat dalam dialog maupun petunjuk teknis yaitu sebagai berikut.

DATA 5

NUNING : Iya, Ibu, jadi apa pun Nuning akan tetap menyanyi Dangdut...!!

(Abe, 2020:102)

Pada kutipan dialog data 5 terdapat kalimat "jadi apa pun Nuning akan tetap menyanyi Dangdut...!!" kutipan tersebut adalah sikap teguh Nuning dalam mempertahankan apa yang menjadi keputusannya. Dalam dialog ini diceritakan jika Ibu Nuning ingin Nuning memiliki pekerjaan yang tetap dan bukan menjadi penyanyi dangdut. Namun Nuning bersikeras pada keputusan untuk tetap menyanyi dangdut. Penggambaran ini masuk kedapalam salah satu tugas dari ego yaitu pengambilan keputusan.

DATA 6

NUNING mengambil parang, lalu bernyanyi dangdut. (Bebas memilih lagunya). NUNING menyanyikan lagu dangdut dengan marah.

NUNING : Kali ini, tak akan mungkin ada lelaki yang berani menggangguku lagi, atau siap kena bacok!

(Abe, 2020:102)

Kutipan data 6 masuk kedalam salah satu tugas dari ego yaitu penyelesaian masalah. Dari kutipan di atas dapat dilihat pada kalimat "Kali ini, tak akan mungkin ada lelaki yang berani menggangguku lagi, atau siap kena bacok!" kalimat ini mengacu pada cerita sebelumnya yaitu Nuning yang selalu di ganggu oleh banyak pria yang 
mendekatinya. Kepopuleran Nuning dalam menyanyi dangdut membuat Nuning memiliki banyak penggemar baik laki-laki atau perempuan. Penggemar laki-laki Nuning seringkali mendekati Nuning, bahkan Nuning sering kali berada dalam bahaya. Maka dari itu, sebagai penyelesaian masalah Nuning membawa parang yang dijadikan sebagai 'temannya' dalam bernyanyi sehingga para lelaki takut untuk mendekatinya.

DATA 7

NUNING : Oalaaah... Mass... Mas... cita-citamu terlalu klise, cita-cita itu adalah kebahagiaan dari dalam diri. Bukan dari luar, mas... dan aku geli sendiri kadang jika mendengar falsafah hidupnya. "Kita harus menunjukkan pada dunia!" Haduuh... yang dimaksud dunia itu apa, siihh...? Berkali-kali aku sudah bilang, cita-citaku hanya ingin menjadi ibu rumah tangga-

(Abe, 2020:107)

Tugas dari ego selain pengambilan keputusan dan penyelesaian masalah adalah penalaran. Penalaran adalah cara berpikir secara logis berdasarkan realita. Pada kutipan data 7 dapat dilihat bahwa Nuning menggunakan pikirannya untuk berpikir secara logis. Pada kutipan tersebut Nuning menentang pemikiran Wawan yang terlalu tinggi dan membandingkan dengan realita yang ada.

\section{Superego}

Superego adalah kekuatan moral dan etika dari kepribadian. Dalam naskah drama Nuning Bacok khususnya pada tokoh Nuning terdapat unsur superego yang terdapat dalam dialog maupun petunjuk teknis yaitu sebagai berikut.

DATA 8

BAPAK : Kok nggrundel ki ngapa?

NUNING : Mboten kok, Pak, sampun, Nuning badhe mirengke ngendikane bapakpun.

(Abe, 2020:94)

Kutipan data 8 menggambarkan sikap Nuning yang menuruti nasihat orang tuanya. Kalimat "Mboten kok, Pak, sampun, Nuning badhe mirengke ngendikane bapakpun." Memiliki arti yaitu "Nggak, Pak, Nuning nurut apa yang di nasehatkan Bapak pada Nuning." dari kalimat tersebut Nuning menahan rasa kesalnya dengan masih berbicara sopan kepada orang tuanya. Hal ini dapat diketahui dari kutipan dialog sebelumnya yaitu pada dialog bapak. 'Nggrundel' dalam bahasa Indonesia adalah sebuah curahan hati, biasanya berupa kekesalan. Kutipan tersebut masuk kedalam kategori superego karena Nuning menahan menghalang kepuasannya untuk mencurahkan emosinya dan masih bersikap sopan kepada orang tuanya

DATA 9

NUNING : : Huft! Kadang sebel juga sih, denger omongan temen-temenku kayak gitu. Tapi aku tetap baik sama mereka, itu karena nasehat ibuku: jangan sampai kebencian itu diperlihatkan di depan orangnya.

(Abe, 2020:95)

Superego merupakan elemen yang mewakili nilai-nilai orang tua mengenai standar sosial yang diajarkan kepada anak melalui berbagai larangan atau perintah dan itu tergambar dalam kutipan data 9. Kutipan tersebut menggambarkan bahwa Nuning 
menahan rasa kesalnya dan tetap berlaku baik sesuai dengan norma dan moral yang diajarkan orang tuanya seperti yang tertera pada kalimat "Tapi aku tetap baik sama mereka, itu karena nasehat ibuku: jangan sampai kebencian itu diperlihatkan di depan orangnya.". Kutipan tersebut menandakan Nuning masih mengingat ajaran orang tuanya untuk selalu bersikap baik.

\section{b) Mekanisme Pertahanan dan Konflik}

Mekanisme pertahanan terjadi karena adanya dorongan atau perasaan beralih untuk mencari objek pengganti. Misalnya impuls agresi yang ditujukan kepada pihak lain yang dianggap aman untuk diserang (Minderop, 2011:29). Dalam naskah drama Nuning Bacok ditemukan lima mekanisme pertahanan dan konflik yang ada dalam diri tokoh Nuning yaitu represi, sublimasi, rasionalisasi (rationalization), reaksi formasi (reaction formation), dan agresi dan apatis. Berikut adalah hasil dari analisis mekanisme pertahanan dan konflik tokoh Nuning yang terdapat dalam naskah drama Nuning Bacok.

\section{Represi}

Represi sebagai usaha dalam menghindari perasaan anxitas. Maka dari itu tindakan represi dibutuhkan untuk memberikan rasa aman dalam diri. Dalam naskah drama Nuning Bacok tindakan represi Nuning tergambar dalam kutipan berikut.

DATA 10

NUNING mengambil parang, lalu bernyanyi dangdut (bebas memilih lagunya). NUNING menyanyikan lagu dangdut dengan marah.

NUNING : Kali ini, tak akan mungkin ada lelaki yang berani menggangguku lagi, atau siap kena bacok!

(Abe, 2020:102)

Kutipan data 10 menggambarkan sikap Nuning yang memutuskan membawa sebuah parang yang selalu ia bawa ketika ia bernyanyi. Parang tersebut ia jadikan sebagai ciri khasnya dalam melakukan pertunjukkan dangdut. Tindakan membawa parang ini disebabkan oleh kejadian tidak menyenangkan yaitu percobaan penculikan yang dilakukan oleh lelaki yang terobsesi padanya yang Nuning alami sebelumnya. Kejadian tersebut membuat Nuning merasa tidak aman. Akhirnya, Nuning memilih untuk membawa parang untuk melindungi dirinya dan memberikan rasa aman pada dirinya saat melakukan pertunjukan dangdut maupun saat ia berada diluar rumah.

\section{Sublimasi}

Dalam naskah Nuning Bacok tindakan sublimasi yang dilakukan oleh tokoh Nuning adalah dengan menyalurkan emosinya dengan bernyanyi. Hal ini membuat emosinya tidak meluap secara negatif dan digantikan oleh sesuatu yang lebih positif seperti bernyanyi dangdut.

DATA 11

NUNING mengambil parang, lalu bernyanyi dangdut (bebas memilih lagunya). NUNING menyanyikan lagu dangdut dengan marah.

(Abe, 2020:102)

Kutipan data 11 menggambarkan bagaimana Nuning bernyanyi dangdut dengan marah. Hal ini sebagai pengalihan rasa marahnya dan meluapkannya dalam bentuk 
nyanyian. Maka dari itu, bernyanyi dangdut adalah tindakan sublimasi yang dilakukan oleh Nuning sebagai cara untuk meluapkan rasa marahnya.

\section{Rasionalisasi (Rationalization)}

Sikap rasionalisasi yang dilakukan oleh tokoh Nuning yang pertama adalah rasa tidak suka yang ia rasakan atas pemikiran dari suaminya Wawan. Nuning merasa pemikiran dari suaminya terlalu tinggi untuk tercapai dan tidak menyadari keadaan mereka yang sebenarnya. Hal ini pula yang menimbulkan perasaan kecewa pada diri Nuning. Keadaan ini tergambarkan dalam kutipan berikut ini.

DATA 12

WAWAN : Tidak, Hon, kita harus menunjukkan pada dunia, hon, bahwa kita berhak menjadi orang yang dihormati. Apalagi aku sebagai suamimu, juga harus ikut dipandang orang. Aku ingin jika ada orang tanya, "Suami Nuning siapa, sih?" mereka kan menjawab dengan sendirinya, "Wawan si Pengusaha kaya!" kita harus punya cita-cita, Ning...

NUNING : Oalaaah... Mas... Mas... cita-citamu terlalu klise, cita-cita itu adalah kebahagiaan dari dalam diri. Bukan dari luar, mas... Dan aku geli sendiri kadang jika mendengar falsafaj hidupnya. "Kita harus menunjukkan pada dunia!" Haduuh... yang dimaksud dunia itu apa sih? Berkali-kali aku sudah bilang, cita-citaku hanya ingin menjadi ibu rumah tangga, punya rumah sendiri di sebuah desa dan mempunyai sepetak kebun dan sawah. Aku ingin menjadi petani. Bersahaja, bukan?

(Abe, 2020:107)

Kutipan data 12 menggambarkan perasaan tidak suka Nuning pada prinsip dan pemikiran suaminya. Sikap rasionalisasi yang dilakukan oleh Nuning selanjutnya adalah memutuskan sebagai penjual tukang potong ayam demi menyambung hidupnya. Keputusan tersebut masuk kedalam salah satu contoh dalam rasionalisasi yaitu kepentingan sebagai alasan.

\section{Reaksi Formasi (Reaction Formation)}

Reaksi formasi adalah tindakan yang dilakukan oleh manusia untuk menutupi fakta yang sebenarnya Konflik batin reaksi formasi terjadi dalam diri tokoh Nuning. Reaksi formasi terlihat dalam kutipan berikut.

DATA 13

NUNING : Wooo... lha, cah lanang edan...!! Minggatt dari rumah ini...!! Leluhurku akan malu jika aku punya lelaki penganggur yang sok perlente, kebarat-baratan, dan sepi tanggung jawab!

NUNING mengambil parangnya lalu membacokkannya di atas meja sambil berteriak:

NUNING : Minggaatttt...!!!

NUNING menangis sesegukan

(Abe, 2020:109)

Pada kutipan data 13 dapat dilihat bahwa Nuning mengusir suaminya dari rumah. Aksi pengusiran ini dilatarbelakangi oleh rasa muak Nuning terhadap suaminya yang 
tidak bisa menghidupi keluarganya dan memenuhi kebutuhan rumah tangganya. Rasa muak ini juga ditambah dengan sikap Wawan yang bergaya perlente dan memiliki gaya hidup yang tidak sesuai dengan keadaan ekonominya. Selain itu, Nuning juga merasa kecewa dengan suaminya karena perubahan perilakunya. Namun walaupun begitu, di sisi lain Nuning masih sangat mencintai Wawan. Ia masih sangat mencintai ayah dari anakanaknya tersebut. Hal ini tergambar dari kutipan berikut.

DATA 14

NUNING : - Oalah, Mas... Mas... panci dan teleman kayu yang kucitacitakan aja belum sanggup kaubelikan. Kuharap kau segera menyadarinya. Dan kembalilah bermain dengan anakanakmu. Aku tahu kau masih mencintaiku, demikian juga aku, Mas. Aku yakin kamu tak akan berpaling dariku. Hati kita telah menyatu sejak awal.

(Abe, 2020:112)

Kutipan data 14 menggambarkan bagaimana Nuning sebenarnya masih mencintai Wawan. Nuning masih berharap agar suaminya berubah dan kembali seperti dulu sebelum mereka menikah. Nuning juga masih menginginkan Wawan untuk kembali ke rumah. Bukti lain yang memperlihatkan bahwa Nuning masih mencintai Wawan dalah Nuning masih merasa kasihan dan tidak tega melihat Wawan harus diam-diam mengambil uangnya untuk bertahan hidup. Walaupun Nuning merasa tidak menyesal telah mengusir Wawan namun ia masih memiliki rasa kasihan padanya. Keadaan tersebut dapat dilihat dalam kutipan berikut.

DATA 15

NUNING $\quad:-$ Hmm... Aku kasihan namun tak menyesal menyuruh Mas Wawan minggat. Sudah berbulan-bulan lamanya ia pergi. Namun aku tahu strateginya bagaimana ia dapat bertahan hidup. Kadang, tanpa sepengetahuanku, ia pulang ke rumah, lalu menyuruh Ali atau Ani tuk mengambilkan uang yang kusimpan. Jika tempatnya terlalu tinggi, Mas Wawan sendiri yang akan mengambilnya. -

(Abe, 2020:110)

\section{Agresi dan Apatis}

Dalam naskah drama Nuning Bacok, ditemukan agresi dalam diri tokoh Nuning. Nuning meluapkan kekecewaanya dan rasa muaknya pada Wawan secara langsung. Tindakan yang dilakukan oleh Nuning dapat dimasukkan kedalam kategori agresi langsung karena Nuning langsung meluapkan emosinya pada Wawan. Tindakan agresi ini dapat dilihat dalam kutipan berikut.

DATA 16

NUNING

WAWAN : Honey, plis... beliv mi. kita kan buktikan pada dunia kalau kita bisa! 


\begin{abstract}
NUNING $\quad$ : Woooo... lha, cah lanang edan...!! Minggatt dari rumah ini...!! Leluhurku akan malu jika aku punya lelaki penganggur yang sok perlente, kebarat-baratan, dan sepi tanggung jawab!

NUNING mengambil parangnya lalu membacokkannya di atas meja sambil berteriak:

NUNING : Minggaatttt...!!!
\end{abstract}

(Abe, 2020:110)

Selain agresi, ditemukan juga sikap apatis dalam diri Nuning. Apatis adalah adalah bentuk lain dari reaksi terhadap kekecewaan, yaitu sikap apatis (apathy) dengan cara menarik diri dan bersikap seakan-akan pasrah. Sikap apatis ini ditemukan pada diri Nuning saat menghadapi cibiran dari orang-orang yang tidak menyukainya. Sikap Nuning dalam menghadapi cibiran ini adalah hanya dengan membiarkannya dan tidak memperdulikannya. Sikap yang dilakukan Nuning dapat dikategorikan sebagai sikap apatis karena memutuskan untuk tidak menganggapinya. Hal ini dapat dilihat pada kutipan berikut.

DATA 17

NUNING

\begin{abstract}
: Huft! Kadang sebel juga sih, denger omongan temen-temenku kayak gitu. Tapi aku tetap baik sama mereka, itu karena nasehat ibuku: jangan sampai kebencian itu diperlihatkan di depan orangnya. Ah, tapi aku tidak membenci temantemanku yang miwir bibirnya. Kuanggap mereka manusia antik yang malah mmbuatku tertawa. Habis apa sih gunany iri, sirik, dan dngki? Apa coba? Nihil kan? Memang orangorang sirik, iri, dengki itu seorang iblis.
\end{abstract}

Kutinggalkan mereka, tinggalkan demi kemajuan bakatbakatku. Masih banyak para tetangga dan teman-teman lain yang mendukungku. Juga semua keluargaku, tentunya.

(Abe, 2020:96)

\title{
Simpulan
}

Berdasarkan tujuan penelitian ini yaitu mengkaji unsur kejiwaan tokoh Nuning yang dibagi dalam dua pokok bahasan yaitu struktur kepribadian tokoh Nuning dan mekanisme pertahanan dan konflik yang ada dalam diri tokoh Nuning. Dari hasil penelitian dapat disimpulkan bahwa pada aspek yang menonjol pada struktur kepribadian adalah aspek $I d$. Hal ini dapat dilihat pada dua mekanisme dasar dalam Id yaitu tindakan refleks dan proses primer. Tokoh Nuning beberapa kali melakukan tindakan refleks dan proses primer dalam aktivitasnya. Dalam aspek ego, Nuning beberapa kali harus dapat mengambil keputusan dan menyelesaikan masalah dalam hidupnya. Dalam aspek supergo, Nuning memiliki moral yang baik dan sopan serta menuruti nasihat-nasihat yang diberikan orang tuanya.

Pokok bahasan lainnya penelitian ini adalah mekanisme pertahanan dan konflik. Berdasarkan hasil penelitian yang dilakukan, dalam naskah drama Nuning Bacok ditemukan lima mekanisme pertahanan dan konflik yang ada dalam diri tokoh Nuning yaitu represi, sublimasi, rasionalisasi (rationalization), reaksi formasi (reaction formation), dan agresi dan apatis. Dari hasil penelitian yang di dapat, represi dilakukan 
oleh tokoh Nuning untuk memberikan rasa aman dalam dirinya. Sublimasi dilakukan oleh Nuning untuk meluapkan rasa emosinya dengan cara yang lain. Sikap rasionalisasi yang dilakukan oleh tokoh Nuning yang pertama adalah rasa tidak suka yang ia rasakan atas pemikiran dari suaminya Wawan. Reaksi Formasi ini terjadi ketika Nuning masih mencintai suaminya namun disisi lain ia juga merasa muak dengan kelakuan suaminya. Pada aspek agresi Nuning meluapkan emosinya secara langsung sedangkan pada aspek apatis in ditemukan pada diri Nuning saat menghadapi cibiran dari orang-orang yang tidak menyukainya

\section{Ucapan Terima Kasih}

\section{Daftar Pustaka}

Abe, Muhammad, dkk. (2020). Dramaturgi Rasa 10 Lakon Lelakon 2020. Yogyakarta. Kalabuku.

Ahmadi, Anas. (2015). Psikologi Sastra. Surabaya. Unesa University Press.

Alwisol. (2018). Psikologi Kepribadian Edisi Revisi. Malang. Penerbit Universitas Muhammadiyah Malang.

Endraswara, Suwardi. (2014). Metode Pembelajaran Drama Apresiasi, Ekspresi, dan Pengkajian. Jakarta. CAPS (Center of Academic Publishing Service).

Melati, T. S., Warisma, P., \& Ismayani, M. (2019). Analisis Konflik Tokoh dalam Novel Rindu Karya Tere Liye Berdasarkan Pendekatan Psikologi Sastra. Parole (Jurnal Pendidikan Bahasa dan Sastra Indonesia), 2(2), 229-238.

Minderop, Albertine. (2011). Psikologi Sastra: Karya Sastra, Metode, Teori, dan Contoh Kasus. Jakarta. Yayasan Pustaka Obor Indonesia.

Piliang, W. S. H. (2016). Mekanisme Pertahanan Diri Tokoh Sentral dalam Antologi Cerpen "Cerita Pendek Tentang Cerita Cinta Pendek" Karya Djenar Maesa Ayu (Kajian Psikologi Sastra). PEKA, 4(2), 164-170.

Riantiarno, N. (2011). Kitab Teater Tanya Jwab Seputar Seni Pertunjukkan. Jakarta. Gramedia Widiasarana Indonesia.

Sugiyono. (2018). Metode Penelitian Kuatitatif, Kualitatif, dan R\&D. Bandung. Penerbit Alfabeta.

Susantono, Nurul P. (2016). Produksi Drama Musikal dari Ide ke Panggung. Jakarta. PT Gramedia Pustaka Utama.

Sumaryanto, A. (2019). Analisis Dan Apresiasi Naskah Drama. Yogyakarta. PT. Penerbit Intan Pariwara.

Sehandi, Yohanes. (2018). Mengenal 25 Teori Sastra. Yogyakarta. Penerbit Ombak 